\title{
Technologies for recovery of energy from wastewaters: Applicability and potential in South Africa
}

\author{
William Stafford \\ Council for Scientific and Industrial Research, Stellenbosch
}

\section{Brett Cohen}

Energy Research Centre, University of Cape Town

\section{Simisha Pather-Elias}

Sustainable Energy Africa

\section{Harro von Blottnitz}

Department of Chemical Engineering, University of Cape Town

\section{Robert van Hille}

Department of Chemical Engineering, University of Cape Town

\section{Sue T L Harrison}

Centre for Bioprocess Engineering Research, Department of Chemical Engineering, University of Cape Town

\section{Stephanie G Burton}

University of Pretoria

\begin{abstract}
This study explored technologies for recovering energy from wastewater through production of biomass, combustion and gasification, generation of biogas, production of bioethanol, heat recovery and microbial fuel cells. A first order desktop analysis of the potential for applying these solutions to wastewaters in South Africa revealed that 3200 to 9000 MWth of energy has potential for recovery, equating to at most $7 \%$ of South Africa's current electrical power supply. Formal and informal animal husbandry, fruit and beverage industries and domestic blackwater were identified as wastewaters with the greatest potential for energy recovery. Of the reviewed technologies, anaerobic digestion shows applicability to the widest range of feedstocks. Net energy generated, reduction in pollution, and water reclamation are identified as the main benefits, but additional benefits such as certified emission reductions, fertiliser production and the production of secondary products may dictate the economic feasibility.
\end{abstract}

Keywords: energy, wastewater, waste, life cycle approach, biomass, biodiesel, combustion and gasification, bioethanol, biogas, South Africa.

\section{Symbols}

$M W_{\text {th }}$ and $M W_{e}$ refer to the thermal and electrical power in megawatt $\left(10^{6} \mathrm{~W}\right)$, respectively. The Lower Heating Value is used for the energy value of fuels in this study.

\section{Introduction}

Wastewaters are generally considered to be a burden to society, and incur energy costs in processing (typically of undetermined magnitude) to allow safe release into the environment. It has been suggested that no other type of intervention has a greater impact upon a country's development and public health than the provision of clean drinking water and the appropriate disposal of waste, especially human waste (SIDA, 2000). 
In South Africa, approximately $40 \%$ of the population is not fully serviced with water and sanitation (Statistics South Africa, 2007), and the sanitation sector and municipal wastewater treatment plants are operated and maintained sub-optimally. Only $4 \%$ of the plants are fully compliant with legislation for discharge into the environment (DWAF, 1998; SABS, 1984; Snyman, 2007). Significant capital investment is needed. This opens opportunities for technological restructuring.

Approximately $20 \%$ of the population also lack access to electricity (Statistics South Africa, 2007), whilst thermal energy needs of households, especially in peri-urban or rural areas, are often still met by polluting fuels such as wood or coal. Whilst South Africa has large resources of coal, it has recognised the need to diversify its energy mix (Macleod, 2007; DME, 2003; NERSA, 2009). One option for diversification and rural electrification is the generation of energy from waste, as an alternative to utilization of energy to treat waste - many industries and local governments operate wastewater treatment plants that consume electrical energy to oxidize organic material in their effluents.

This paper explores technologies with potential to generate energy concomitantly with treating wastewater for safe discharge into the environment. Established and emerging technologies for generating energy from wastewaters are reviewed and the characteristics and energy potential of wastewaters in South Africa are determined. The feasibility of applying appropriate technologies to different waste streams is explored within the context of a life cycle approach.

The paper is based on a study funded by the Water Research Commission, and is based on data gathered from existing literature and inputs gathered from stakeholders consulted during the process. Further information on data used as inputs into the study, and a complete set of results, is contained in the project report (report number 1732/1/09) which may be downloaded from the Water Research Commission website or obtained directly from the authors.

\section{Approach to determining energy potential from wastewater}

In order to relate various technological options for energy recovery from wastewater, it is necessary to distinguish process streams with respect to their potential as energy sources, according to input streams, process intermediates and energy outputs as follows:

- Inputs: The chemical potential energy is carried in wastewaters in the form of carbonaceous material (suspended or dissolved, and mostly in diluted form). Exceptions are energy in the form of heat (for wastewaters above ambient temperature) and the use of wastewaters as growth media owing to their inorganic constituents for organisms to fix carbon dioxide using the energy of sunlight (photosynthesis).

- Intermediates: Typically, the energy produced will be as an intermediate fuel such as gaseous hydrogen or methane, liquid ethanol or biodiesel or solid dry biomass.

- Outputs: Intermediate fuels may be sold as energy products or used on site for generation of heat or electricity or both, or in vehicles for propulsion. The conversion of thermal to electrical energy usually involves large losses, with typical efficiencies of only 25 to $35 \%$ in current technologies. Hence, combined application of heat and power, which allows for higher recovery efficiencies, is also considered.

With this distinction in place, it is possible to identify technologies that:

- convert inputs into intermediates, such as the production, separation and drying of biomass (harnessing carbon-bound energy, nutrients or heat); anaerobic digestion to produce biogas; fermentation to produce bio-ethanol; and synthesis of lipids for conversion to biodiesel;

- convert intermediates into outputs, such as combustion of solid, liquid or gaseous intermediates to raise steam or turn internal combustion engines, or gasification of such intermediates for use in gas turbines or combined cycle applications;

- convert inputs directly into outputs, such as heat recovery via heat pumps, and microbial fuel cells to generate electricity.

In order to estimate the national potential for energy recovery from wastewaters, each of these technologies must first be understood in terms of physical, chemical and biological principles and constraints, and in terms of maturity and current level of penetration (Section 3). Potential inputs must then be described and quantified on a sector by sector basis using likely conversion efficiencies or yield factors from the literature to estimate the total national potential (see Section 4).

Having developed an estimate of national potential, Section 5 presents a support framework for decision making on technology choice and implementation. Feed stream characteristics are matched with appropriate technology, and constraints to their operation and application are identified.

\section{Technologies appropriate for harnessing energy from wastewater}

Table 1 presents an overview of the technologies available for recovering energy from wastewater streams. The principles of these technologies are discussed in Section 3.1. Case studies on their 
Table 1: Comparison of appropriate energy from wastewater technologies

\begin{tabular}{|c|c|c|c|c|}
\hline Technology & $\begin{array}{c}\text { Wastewater } \\
\text { characteristics }\end{array}$ & Advantages & Disadvantages & Comments \\
\hline $\begin{array}{l}\text { Fermentations } \\
\text { for biomass } \\
\text { and secondary } \\
\text { products }\end{array}$ & $\begin{array}{l}\text { - Nutrients }(\mathrm{C}, \mathrm{N}) \\
\text { - Non-toxic effluent } \\
\text { for microbial growth } \\
\text { - Dissolved or suspend } \\
\text { organic }\end{array}$ & $\begin{array}{l}\text { - Can produce high } \\
\text { value secondary met-a } \\
\text { bolites as by-products } \\
\text { - Can remove toxic } \\
\text { and recalcitrant } \\
\text { chemicals }\end{array}$ & $\begin{array}{l}\text { - Chemicals such as } \\
\text { phenol are inhibitory. } \\
\text { - pH, salinity, aeration } \\
\text { need to be adjusted } \\
\text { for growth of the } \\
\text { microbe }\end{array}$ & $\begin{array}{l}\text { - More biomass produced from } \\
\text { aerobic compared to } \\
\text { anaerobic fermentations. } \\
\text { - Biomass production for use } \\
\text { as a feedstock for bioethanol } \\
\text { production and for gasification. }\end{array}$ \\
\hline $\begin{array}{l}\text { Anaerobic } \\
\text { digestion }\end{array}$ & $\begin{array}{l}\text { - Works best at warmer } \\
\left(30-60^{\circ} \mathrm{C}\right) \text { temperatures } \\
\mathrm{pH}: 5.5-8.5 \\
\text { - Good design to control } \\
\text { digestion and collection } \\
\text { of gas } \\
\text { - Dissolved or suspend } \\
\text { organic }\end{array}$ & $\begin{array}{l}\text { - Suitable with most } \\
\text { substrates } \\
\text { - Can achieve } 90 \% \\
\text { conversion } \\
\text { - Help contain odour } \\
\text { - Produces biogas for } \\
\text { heating, electricity } \\
\text { generation and steam } \\
\text { - Produces less biomass } \\
\text { than aerobic fermentation }\end{array}$ & $\begin{array}{l}\text { - } \mathrm{H}_{2} \mathrm{~S} \text { oxidised to } \mathrm{SO}_{2} \text { and } \\
\text { when combined with water } \\
\text { vapour can form sulphuric } \\
\text { acid which is corrosive } \\
\text { - High capital investment }\end{array}$ & $\begin{array}{l}\text { - Produces biogas fuel rich in } \\
\text { methane/hydrogen }(60 \%) \\
\text { and carbon dioxide }(40 \%) \\
\text { - The bio-liquid and sludge can be } \\
\text { used as fertiliser and compost } \\
\text { for soils, as feed for biodiese } \\
\text { production or can be gasified }\end{array}$ \\
\hline $\begin{array}{l}\text { Combustion } \\
\text { Gasification }\end{array}$ & $\begin{array}{l}\text { - Biomass } \\
\text { - Low water content and } \\
\text { suspended organic matter }\end{array}$ & $\begin{array}{l}\text { - Heat energy } \\
\text { - Destruction/conversion } \\
\text { of all hazardous material } \\
\text { - Mature technology avail- } \\
\text { able } \\
\text { - } 95 \% \text { fuel-to-feed efficiency }\end{array}$ & $\begin{array}{l}\text { - Electricity costs are higher } \\
\text { than for a coal-fired } \\
\text { power station. } \\
\text { - Could produce hazardous } \\
\text { off-gases } \\
y\end{array}$ & $\begin{array}{l}\text { - Organic compounds are converted } \\
\text { to syngas for use as power, chemi- } \\
\text { cals, Fischer-Tropsch liquids and } \\
\text { gaseous fuels, fertiliser and steam } \\
\text { - Metals can be recovered } \\
\text { - Ash and tar wastes }\end{array}$ \\
\hline $\begin{array}{l}\text { Algal growth } \\
\text { for biodiesel } \\
\text { production }\end{array}$ & $\begin{array}{l}\text { - Phosphate and nitrogen } \\
\text { sources } \\
\text { - Non-toxic effluent for } \\
\text { growth } \\
\text { - Dissolved organic - COD } \\
\text { removal with heterotrophic } \\
\text { growth }\end{array}$ & $\begin{array}{l}\text { - Low energy requirements } \\
\text { - use energy of sunlight } \\
\text { for algal growth } \\
\text { - Can result in } \mathrm{CO}_{2} \\
\text { sequestration } \\
\text { - Can utilise dilute waste } \\
\text { water streams }\end{array}$ & $\begin{array}{l}\text { - Algal ponding area can } \\
\text { represent considerable land } \\
\text { area } \\
\text { - Photobioreactors have } \\
\text { large capital costs } \\
\text { - No suspended solids } \\
\text { - Evaporation }\end{array}$ & $\begin{array}{l}\text { - Algal oils that are converted to } \\
\text { biodiesel fuel by transesterification } \\
\text { by-product filter cake rich in } \\
\text { proteins and carbohydrates } \\
\text { from algae } \\
\text { - Valuable secondary products }\end{array}$ \\
\hline $\begin{array}{l}\text { Bioethanol } \\
\text { production }\end{array}$ & $\begin{array}{l}\text { - Carbon and nitrogen } \\
\text { sources } \\
\text { - Non-toxic effluent for } \\
\text { microbial growth } \\
\text { - Carbohydrate (sugar) rich } \\
\text { - Dissolved organics (or } \\
\text { suspended with emerging } \\
\text { technology) }\end{array}$ & $\begin{array}{l}\text { - Established technology } \\
\text { producing fuel suitable for } \\
\text { a variety of combustion } \\
\text { engines }\end{array}$ & $\begin{array}{l}\text { - Cost of carbohydrate rich } \\
\text { raw materials } \\
\text { - Large volumes of } \\
\text { bioreactors needed } \\
\text { - Non-dilute waste waters } \\
\text { required }\end{array}$ & $\begin{array}{l}\text { - Ethanol fuel, carbon dioxide and } \\
\text { biodunder }\end{array}$ \\
\hline $\begin{array}{l}\text { Microbial fuel } \\
\text { cells }\end{array}$ & $\begin{array}{l}\text { - Non-variable waste } \\
\text { water sources } \\
\text { - Non-toxic effluent for } \\
\text { microbial growth } \\
\text { - Dissolved organics }\end{array}$ & $\begin{array}{l}\text { - Can be used at less } \\
\text { than } 20^{\circ} \mathrm{C} \\
\text { - Suitable for use with low } \\
\text { concentration of organics } \\
\text { in waste waters } \\
\text { - Efficient (direct conversion } \\
\text { to electricity) }\end{array}$ & $\begin{array}{l}\text { - Capital intensive } \\
\text { - Still in development } \\
\text { - Variable COD reduction } \\
\text { depending on waste water } \\
\end{array}$ & $\begin{array}{l}\text { - Direct conversion of waste } \\
\text { to electricity } \\
\text { - Off-gas mainly carbon dioxide } \\
\text { Some microbial sludge formed }\end{array}$ \\
\hline Heat recovery & $\begin{array}{l}\text { - Waste waters with temp- } \\
\text { erature above ambient }\end{array}$ & - Direct heat recovery & $\begin{array}{l}\text { - Heat above ambient and } \\
\text { the need for heat energy }\end{array}$ & $\begin{array}{l}\text { - Heat for household heating, steam } \\
\text { generation, reduces electricity } \\
\text { requirements }\end{array}$ \\
\hline
\end{tabular}

application are presented in Section 3.2 while more complex, integrated applications are reviewed in Section 3.3.

\subsection{Physical, chemical and biological principles and constraints}

\subsubsection{Utilisation of waste heat}

Thermodynamic theory suggests that the recovery of waste heat contained in one stream to heat another can be implemented at any scale, providing there is a suitable heat gradient between the two streams, and that they are separated by a good heat conductor. The flow rate of the wastewater also affects the suitability for heat exchange. Planned integrated applications for waste heat utilisation through application of Pinch analysis allows for the greatest opportunities for energy recovery to be achieved (Rossiter, 1995).

\subsubsection{Production and utilisation of biomass}

Various forms of biomass have potential for energy generation. These can be realised via thermal (gasification or combustion), anaerobic digestion or via fermentation routes. Energy products generated include steam and/or electric power, or liquid 
and/or gaseous fuel for use in a distributed energy network. In assessing the potential for energy generation from wastewater biomass, both the wastewater sludges (a form of biomass) and the growth of organisms (fungi, plant and algae biomass) on these wastewaters for use in fuel generation are considered. Use of such waste material for energy generation may, however, compete with its potential use in agriculture.

The following opportunities for biomass production from wastewaters are identified:

Production of plant biomass: Wastewater has been shown to be an effective fertiliser for crop cultivation, and could hence be used for the production of plant biomass for energy recovery. The average person's annual production of faeces (containing $0.4 \mathrm{~kg}$ total nitrogen and $0.2 \mathrm{~kg}$ total phosphorus) and urine (containing $3 \mathrm{~kg}$ total nitrogen and $0.3 \mathrm{~kg}$ total phosphorus) render it capable of fertilising up to $600 \mathrm{~m} 2$ of land area for plant biomass (Jönsson et al., 2004). Concerns for the safety of the environment and human health necessitate that utilisation of waste water sludge for land applications be subjected to governmental regulation. Large South African cities such as Johannesburg and Cape Town successfully operate bulk land applications schemes for their sewage sludge in partnership with grain farmers (Alcock, 2009; DWAF, 1998). Both the sludge from anaerobic digesters and algal biomass have demonstrated effective potential as fertilisers contributing to soil fertility and soil carbon sequestration (Paustian et al., 1998). Further, the treated wastewaters from crude water treatment of industrial waters (containing no pathogens) that do not meet standards for disposal to river are recognised as being of value for irrigation; subject to meeting certain requirements (Emanti Water and Environmental Engineering Services, 2012). The use of these wastewaters for the growth of terrestrial plants can thus result in a valuable fuel source while also mitigating greenhouse gas emissions by sequestering carbon dioxide in the soil.

Microbial biomass: Microbial systems, including bacteria, yeast and fungi, utilise a broad spectrum of organic compounds over a range of concentrations for the production of biomass and hence can be readily grown in wastewaters. Typically, these systems are characterised by a high affinity for substrates that enables them to metabolise soluble organic pollutants at low residual concentrations. Such biomass can be removed from the wastewater through phase separation (e.g. settling) and thereby provide a concentrated resource for energy generation through a variety of technologies.

Growth of algal biomass for biodiesel production and other energy products: Certain species of algae which can be grown in wastewaters produce large quantities of oil as a storage product (up to $80 \%$ dry weight) and are potentially up to 23 times more productive with respect to oil per unit area than the best oil-seed crop (Paustian et al., 1998). Conservatively, algal productivity exceeds palm oil by 10 fold and jatropha, canola and sunflower crops by more than 30 fold in terms of oil produced per unit area (Barsanti et al., 2006; Sazdanoff, 2006). In addition to oil transesterification to alkyl esters of the fatty acids (biodiesel), glycerol and algal biomass can be used to produce by-products. Glycerol may be burned directly as a fuel, or converted by fermentation to ethanol and hydrogen as energy products (Ito et al., 2005). Algal biomass, like other biomass, can to be processed to a variety of energy products, including heat, steam, electricity, syngas and liquid fuels, and biogas. The algal system has several advantages including capacity to use brackish or saline waters and wastewaters (Tsukahara and Sawayama, 2005), and reduced need for external aeration during wastewater treatment due to photosynthetic oxygen (Munoz and Guieysse, 2006). The financial feasibility of algal biodiesel production can be enhanced by simultaneous wastewater treatment, production of animal feeds or production of valuable secondary products (Chisti, 2007; ECOWORLD, 2006; Reith et al., 2000; Tsukahara and Sawayama, 2005).

\subsubsection{Combustion and gasification}

The heating of biomass in the presence of a limiting oxygen supply results in gasification and the production of syngas. Syngas consists primarily of a mixture of carbon monoxide, carbon dioxide and hydrogen that may be used as a combustion fuel (heat energy value of $8-14 \mathrm{MJ} / \mathrm{kg}$ or $10-20$ $\mathrm{MJ} / \mathrm{Nm}^{3}$ ), or may be converted to liquid fuels using a biological or chemical process. Syngas can be used to produce synthetic petroleum via the Fischer-Tropsch synthesis or via the methanol to gasoline process. Alternatively, the carbon monoxide of the syngas can be transformed into ethanol by the anaerobic bacteria, with typical yields of 340 litres ethanol per tonne (of municipal solid waste, biomass waste, animal wastes etc.) (Techmonitor, 2005). The combustion of biomass (or syngas) in the presence of an excess oxygen supply results in complete oxidation and the formation of hot flue gases that are typically used to produce steam to drive electric turbines for electricity production, with an efficiency of approximately $30 \%$.

If the heat energy is also captured, providing combined heat and power (CHP), the efficiency can be increased to upwards of $50 \%$ and as high as $80 \%$. The feasibility of applying combustion or gasification is related to moisture content, and the operational problems of tar formation, mineral content, over-bed burning and bed agglomeration. The 
feedstock must be relatively dry; with a maximum moisture content of 40 to $50 \%$. Dryers may be included in the design, but there is a clear trade-off between the amount of energy available in the feedstock and the amount of energy expended on drying. There are several potential negative environmental effects as a result of the gaseous and solid phase pollutants which are potentially produced from application of these technologies, including heavy metals, dioxins, furans and $\mathrm{NO}_{\mathrm{x}}$ gases. The types and concentrations of pollutants are strongly dependent on the nature of the feedstock and are not considered further as part of this work. However, evidence suggests that these emissions can be controlled through technological interventions.

\subsubsection{Anaerobic digestion to produce biogas}

Biogas is produced by anaerobic digestion of organic matter using microorganisms in an oxygenfree environment. Biogas production involves several stages carried out by a variety of microorganisms: In initial hydrolysis reactions, microorganisms convert complex organic compounds into less complex organic compounds which are then converted to organic acids. Methane forming microorganisms then utilise these acids to form methane, the main component of biogas. Biogas is a mixture of gases, typically containing of $50-70 \%$ methane. Additionally, hydrogen may be produced by anaerobic digestion, either as a component of the biogas or as the major product. The latter requires the microbial population to be dominated by specific organisms, such as Rhodobacter or Enterobacter species. Current models indicate significantly greater energy recovery as methane from biomass digestion. With developing fuel cell technology, hydrogen fermentation may become more attractive (Levin et al., 2007). Biogas can be used in many applications (stoves, boilers) with little modification. For applications in combustion engines (generators, motor car engines), the gas requires considerable upgrading to remove non-methane components.

Although biodigesters are relatively easy and cost effective to establish, they need to be properly maintained in order to ensure optimal operation.

\subsubsection{Fermentation to bioethanol}

The production of bioethanol as a renewable liquid fuel is well established. Bioethanol can either be used on its own or blended with conventional liquid fuels to form either Gasohol or Diesohol (Bailey and Ollis, 1986). Typically, bioethanol is formed by fermentation of simple sugars such as glucose and fructose under anaerobic conditions. Many yeasts, such as Saccharomyces sp. and some bacteria such as Zymomonas sp., carry out this fermentation (Shuler and Kargi, 2002). The current challenges are to use waste streams in which the organic car- bon is not present as simple sugars by using chemical or biological pre-treatment or novel microorganisms that ferment a broader range of organic substrates. There is currently a significant research focus on cellulolytic pre-treatment methods. The low ethanol yields (typically $10 \%(\mathrm{v} / \mathrm{v})$ ) obtained in fermentation currently demand subsequent energy intensive distillation. Conventional ethanol plants may expend more than $30 \%$ of the heat energy of the bioethanol fuel in the distillation process.

\subsubsection{Microbial fuel cells}

Fuel cells convert chemical energy into electrical energy. Microbial fuel cells operate by using bacteria that oxidise organic matter in the wastewater to transfer electrons to an anode from where they travel via a circuit to the cathode to combine with protons and oxygen to form water. The difference in the potential coupled to electron flow produces electricity. Microbial fuel cells are an emerging technology, and a number of these have been operated successfully with both pure cultures and mixed cultures that were enriched either from sediment or activated sludge from wastewater treatment plants. Wastewaters of very different characteristics can be used: sanitary wastes, food processing wastewater, dairy manure, swine wastewater and corn stover (Logan et al., 2005; Min et al., 2005; Rabaey and Verstraete, 2005). Essentially, this technology can use bacteria already present in wastewater as catalysts to generate electricity while simultaneously treating wastewater, but its development is hampered by low power output and high material costs (Logan and Regan, 2006). To date, microbial fuel cells have not been developed in large scale applications, but are being used to generate energy for BOD (biological oxygen demand) sensors, robots and small telemetry systems (Leropoulos et al., 2005; Shantaram et al., 2005).

\subsection{Application of technologies for energy from wastewater}

Worldwide, examples exist of where energy is recovered from wastewaters to yield a variety of energy products at varying scales (from small rural to large industrial operations). A small selection of examples is provided to highlight the potential of the energy from wastewater technologies.

Heat integration: At the Bruce Eco-Industrial Park in Canada, forward-planning to integrate energy usage was applied. The Centre is situated adjacent to the nuclear Ontario Power station for the supply of steam heat for several facilities, including alcohol distillation, food and feed manufacture, a plastic manufacturer, and a greenhouse (/www.bruce-eco. $\mathrm{com} /$ ). At the Kalundborg power station in Denmark, the existing plant was adapted to supply excess heat for a local refinery, pharmaceutical and 
enzyme manufacturing factories, and domestic heating; thereby replacing approximately 3500 household oil-fired units and supplying $15 \%$ of the refinery's energy needs. Low grade waste heat is also be utilised in the heating of water in aquaculture applications such as the Asnæes trout fish farm in the Kalundborg complex (http://www.symbiosis.dk/). In other examples, heat pumps have been used to recover and upgrade the low grade heat for a city's hot water distribution system (City of Vancouver, undated), or to maintain the temperatures of on-site industrial processes.

Domestic biogas: The Chinese government began a mass implementation program for household biogas in 1975. Within a few years units were being constructed at a rate of 1.6 million per year. The technology has continued to be developed and implemented and in 2005 China had 17 million digesters with annual production of 6.5 billion $\mathrm{m}^{3}$ biogas. Importantly, biogas provides energy to one quarter of households in rural areas. This pattern of rapid introduction of biogas units was repeated in India, Nepal, Vietnam and Sri Lanka. There are currently over 2 million family-sized units in operation in India, and over 200000 families a year are switching from the traditional fireplace to biogas for cooking and heating (Singh and Sooch, 2004).

By contrast, in South Africa (and Africa as a whole) implementation has been minimal, despite the high costs of alternatives in rural settings such as the construction and servicing of ventilation improved toilets. Initial capital costs and the maintenance levels required have been higher than expected and household-level operational experience has been lacking (World Energy Council, 2007).

Agricultural biogas: Meili village (Zhejiang Province, China) slaughters 28000 pigs, 10000 ducks, 1 million ducklings and 100000 chickens each year and the wastewaters are fed to an anaerobic digester that produces enough biogas for more than 300 households and 7200 tonnes of organic fertiliser each year (ISIS, 2006). A similar process is used in Linköping (Sweden) where the biogas is upgraded to vehicle fuel quality for all public transport vehicles in the city ( $>60$ buses), converted to run on biogas in 2005 (IEA Biogas, undated). In Ireland, wastewater from farms in Ballytobin and food processing industries generate electrical and heat energy for the small farming community by means of anaerobic digesters. This plant generates an estimated $150000 \mathrm{kWh}$ of electricity and $500000 \mathrm{kWh}$ of heat energy per year using gas turbines and combined heat and power (IEA Bioenergy, undated).

In the agricultural town of Hamlar, Germany, biogas is used to generate $680 \mathrm{~kW}$ of heat and electricity in a combined heat and power facility (INNOVAS and DGE GmbH, undated). Waste herb stalks from an operation which supplies $80 \%$ of Germany's herb market, potato skins and blood from chicken slaughter-houses are fed into anaerobic digesters of $885 \mathrm{~m}^{3}$ capacity at a loading of 100 tonnes per day, following initial pre-treatment. The heat from biogas combustion is used for herb drying and pre-treatment (pasteurisation and heating the fermenter to $35-40^{\circ} \mathrm{C}$ ). Economic incentives for renewable energy result in the plant selling all of its electricity to the grid at a very favourable rate and buying back the electricity it requires.

Bioethanol: A few examples of the use of wastewater and wastewater sludges for the production of bioethanol have been reported. The VTT Technical Research Centre of Finland has developed technology for the distributed production of ethanol by fermentation of food processing wastewaters. This technology enables production even at a small scale and is estimated to have potential to meet $2 \%$ of the total volume of petrol sold in Finland and is currently being commercialised by St1 Biofuels Oy (VTT, 2006).

\subsection{Integrated technologies for energy production from wastewater}

Although streams and technologies can be individually matched, the integration of technologies and waste streams holds the greatest promise in attaining long-term energy security while maximising wastewater treatment. There are several examples where this has been successful.

Integrated algal biodiesel: Historically it has been suggested that algal biodiesel is financially feasible only with concomitant wastewater treatment or production of animal feed, valuable secondary products or additional energy products. More recent analysis indicates that recovery of algal biodiesel from wastewaters can be profitable with a reasonable breakeven after 2 to 4 years (ECOWORLD, 2006; Reith et al., 2000). There has recently been much speculative interest in algal biodiesel, had primarily been fuelled by the increased diesel price prior to the 2008 reversal. Several new companies have been started, proposing to use algae for producing biofuels and acquiring certified emission reductions (CERs) through $\mathrm{CO}_{2}$ mitigation (IGV $\mathrm{GmbH}$, undated). An example is Aquaflow Bionomic (New Zealand) who report that they are harvesting crude oil, to refine into paraffinic kerosene for use as jet fuel, from wild algae cultured on oxidation ponds used in the treatment train of domestic and agro-industrial waste streams. This facility handles 5 billion litres of water per year in a $60 \mathrm{Ha}$ facility (Kiong, 2006). Further developments will reveal whether such projects are financially feasible and will be implemented for production rather than demonstration purposes. 
Advanced integrated wastewater pond systems: These (Oswald, 1995) have been shown to be effective in treating municipal wastewaters in South Africa (Rose et al., 1981; Rose et al., 1993; Shipin et al., 1998). They consist of an anaerobic digester and high rate algal pond. A system in Grahamstown, South Africa, has been monitored for wastewater treatment efficacy over nine years. Levels of nutrient and organic removal comparable with conventional wastewater treatment works and negligible E.coli counts were achieved (Wells, 2005). The biogas from anaerobic digestion provides energy and the algae can be used as a fertiliser or fuel (e.g. biodiesel).

Despite these and many other international examples of energy from wastewater projects, there is no overall view of the potential nor a strategy for harnessing this renewable energy source in many countries. In South Africa, only a few examples of recovery of energy from wastewater are recorded. Several municipal wastewater treatment plants use anaerobic digesters as part of the wastewater treatment process. However, the majority vent or flare the gas while some use the heat internally to maintain digester temperatures and to heat building space. This demonstrates that energy use has been poorly integrated and the opportunities for mitigating greenhouse gas (GHG) emissions have not been realised. One exception is the Cape Flats wastewater treatment plant in Cape Town where equipment has been installed to use biogas to dry and pellet the wastewater sludge, thereby reducing the on-site disposal costs and environmental burdens (eutrophication of the nearby freshwater lake, Zeekoevlei) while providing a potential energy source (ILEC, undated). The pellets have an energy content of $\sim 16.6 \mathrm{MJ} / \mathrm{kg}$ and have been used by a local cement factory as additional fuel in their kilns. While operation has been interrupted, analysis has indicated that the Cape Flats plant could generate anaerobic digestion biogas to be self-sufficient in its basic energy requirements, and a project is underway to refurbish the three $6000 \mathrm{~m}^{3}$ digesters. This project was almost complete at the time of writing.

A combined heat and power plant has been commissioned at PetroSA's gas-to-liquids refinery in Mossel Bay to utilise the biogas produced from wastewater treatment. The electrical output replaces 4.2 MW of grid-based electricity and the plant is expected to produce approximately 33000 tonnes per year of certified emissions reductions (CERs). Along with receiving debt financing from the Development Bank of South Africa, the sale of emissions credits has contributed to the PetroSA project's economic viability (van der Merwe, 2007). Finally, there are also isolated installations of household, community scale and small-scale industrial anaerobic digesters in the country (AGAMA Energy, 2007).

\section{Wastewater energy potential in South Africa}

In this study, the energy potential from several sectors was surveyed to obtain first order estimates of the loads, characteristics and energy potential from various wastewaters in South Africa. The survey included information derived from studies reported previously, interviews with practitioners and stakeholder workshops across several sectors. The energy potential from the wastewater was calculated from the surveyed loads and by application of an energy estimate of $15 \mathrm{MJ} / \mathrm{kg}$ for biomass or chemical oxygen demand (COD). This broad approach was required to accommodate the various downstream energy options while being applicable to waste streams that varied in their characteristics. The calculations did not take into account the energy costs in collection or transport of these wastes, but the seasonality, and distribution are commented upon.

In Table 2, the primary wastewaters for their energy potential are identified. These include domestic blackwater, animal husbandry waste waters, agri-waste waters, waste waters from the distillery and breweries, and the textile, paper and pulp and petrochemical industries. The basis of the calculation of energy potential for each source and its underpinning assumptions are detailed in the table, leading to the report of an approximate energy potential. Overall, the estimated total energy generation potential from the wastewater streams surveyed lay between 3200 and $9000 \mathrm{MW}_{\text {th }}$. The wide variation in these values reflects variability in source data. These sensitivities are highlighted.

The greatest energy potential was identified for wastes from animal husbandry activities, in particular poultry farms and cattle. The energy potential from poultry farm waste waters, a major sector of South African agricultural industry, were estimated as 940 to 2980 MWth. This was followed by the domestic blackwater stream, which was estimated to have the capacity to generate of the order of 840 $\mathrm{MW}_{\text {th }}$.

\section{Supporting decision-making for developing energy from wastewater}

Decisions on harnessing the potential of energy from wastewater are best informed by decision support tools such as a life cycle approach by which the costs (CAPEX, operations and maintenance, environmental burden incurred) and benefits (energy recovery, reductions in solid liquid and gas pollutants and the benefits of secondary products) of technologies appropriate to a given wastewater can be assessed and compared. Figure 1 shows the considerations which should be taken into account in this decision process.

A pre-feasibility study is required to provide the types and yields of energy products. Matching 
Table 2: Energy potentials of waste waters from various sectors in South Africa

\begin{tabular}{llrl}
\hline $\begin{array}{l}\text { Wastewater } \\
\text { stream }\end{array}$ & Volume produced & Approach to calculation & Energy potential: \\
Thermal power
\end{tabular}

(MWth)

Domestic $200 \mathrm{~L} /$ day wastewater per person

blackwater Population of SA $=48.5$ million,

(human hence $9,70 \times 10^{9} \mathrm{~L} /$ day is generated

faeces) COD estimated at $0.860 \mathrm{~g} / \mathrm{L}$,

Energy content $=15 \mathrm{MJ} /$

Municipal treatment plants serve only $60 \%$ of the

population, therefore only $60 \%$ of human faeces are

509-842

currently captured. These plants are distributed;

approximately 968 WWT plants exist in SA. The

majority of these plants are small at $<0.5 \mathrm{ML} /$ day, with

larger plants of $2.5 \mathrm{ML} /$ day. Treatment plants also receive

domestic urine, greywater and industrial load, not considered here.

\begin{tabular}{ll}
\hline Animal & Cattle in feedlots Mixed solid and liquid waste slurries. \\
husbandry & These represent point sources which could be accessed \\
& through on-site energy recovery. 9 feedlots represent more \\
& than half the total cattle in feedlots
\end{tabular}

$79-215$ than half the total cattle in feedlots

Rural cattle Considers solid waste only, collected at night $1271-3445$

in kraals. Only a small percentage of this energy is

realistically recoverable

Dairies Mixed solid and liquid waste slurries collected,

$117-121$

including washing and milk spills. Represent point sources

which could be accessed through on-site energy recovery

Piggeries Mixed solid and liquid waste slurries. Represent 18-715

point sources which could be accessed through on-site

energy recovery

\begin{tabular}{lllc}
\hline & Poultry farms Considers solid wastes only & \multicolumn{1}{c}{$940-2976$} \\
\hline $\begin{array}{l}\text { Olive } \\
\text { production }\end{array}$ & $100 \mathrm{~g} / \mathrm{L} ; 89 \mathrm{ML} /$ year & Red meat and poultry abattoirs Considers liquid wastes only & $1-55$ \\
\hline
\end{tabular}

Fruit $\quad 20 \%$ of 2100000 ton citrus fruit

processing (2005) was used

Distributed and seasonal. Only the wastewaters from

68

For juice, waste water $\mathrm{COD}=15 \mathrm{~g} / \mathrm{L}$;

205000 ton deciduous fruit processed

canning and juicing in the Western Cape are considered

(pulp and pomace excluded). Operates 4 month

by the canning industry in 1999/2000

of the year

for which the waste water COD

averages $5 \mathrm{~g} / \mathrm{L}$.

\begin{tabular}{ll}
\hline Winery & 0.7 and $3.8 \mathrm{~m}^{3} /$ ton of grapes processed \\
& $(0.8-4.4 \mathrm{~L} / \mathrm{L}$ of wine produced $)$ \\
& $\mathrm{COD}=6 \mathrm{~g} / \mathrm{L} ; 1000 \mathrm{ML} /$ year of wastewater
\end{tabular}

Distillery

Distributed. Grain, grape and sugar-cane (molasses)

considered. Compared to grain and grape, molasses has

the greatest energy potential, is not seasonal and is less distributed (3 major plants, all in $\mathrm{KZN}$ ).

\begin{tabular}{lll}
\hline Brewery & Distributed. 7 breweries & 17 \\
\hline Textile industry & Distributed & 22 \\
\hline Pulp and paper & 17 mills & $45-100$ \\
\hline $\begin{array}{l}\text { Petrochemical } \\
\text { waste }\end{array}$ & $\begin{array}{l}\text { PetroSA produces 12 MW from biogas } \\
\text { to electricity plant }\end{array}$ & $\begin{array}{l}\text { Sasol assumed to produce 3x more based on plant size. } \\
\text { PetroSA and Sasol.. 4 refineries. One gas to liquid fuel } \\
\text { refinery }\end{array}$ \\
\hline
\end{tabular}

wastewater streams with energy potential to the appropriate technologies requires simultaneous consideration of stream characteristics and the operational parameters for the efficient functioning of an appropriate technology. An approach to matching streams and technology considerations is presented in Table 3. Here the waste waters are classified into streams of dissolved solids, suspend- ed solids and sludge. In each case, the potential role of the technologies identified in Section 3.1 is assessed and an energy rating per unit waste given.

In addition to the observations in Table 3, the following are important considerations in a feasibility study:

- The most appropriate technologies and their limitations are partly determined by the value of 


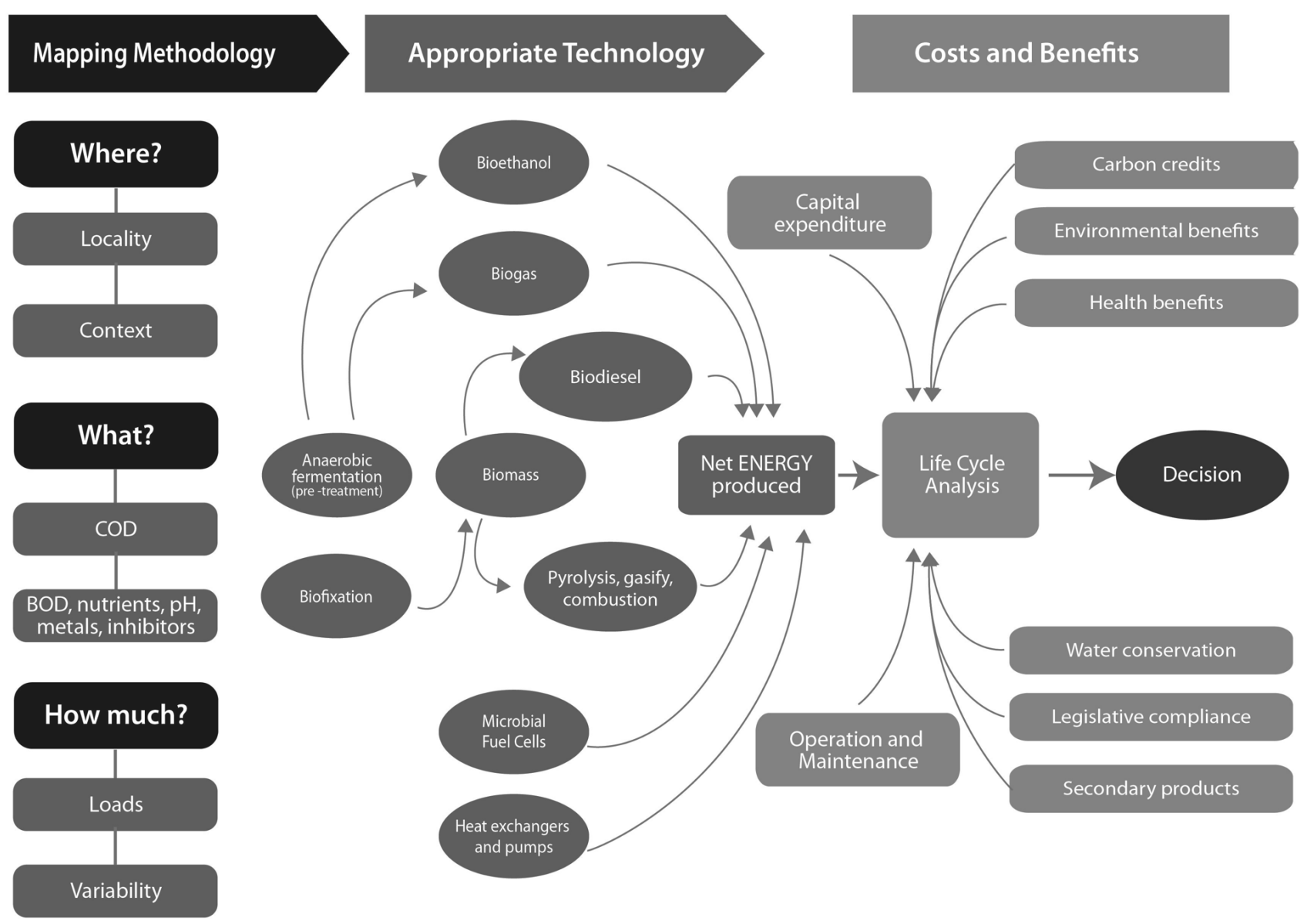

Figure 1: Mind-map illustrating the approach taken in assessing energy from a wastewater project

the required energy product (heat, electricity, combined heat and power or fuel) and the driving market forces that determine how this fuel can be used with current technology.

- The ease of separation of the energy fuel product from water is often the key to feasibility. For example, biogas separates easily from the wastewater by phase separation whereas bioethanol requires energy intensive distillation.

- Anaerobic biogas was found to be an internationally established flexible technology for treatment of dissolved solids, suspended solids and sludges. The latter require pre-treatment to maximise degradation, a current area of technological development. Anaerobic digestion is suitable for application with rural/household sewage, (particularly since $40 \%$ of South African communities are not serviced with waterborne sewage), as well as municipal wastewater treatment plants and agricultural communities. However, skilled management and skills-training is required if anaerobic digestion is to be applied successfully in South Africa.

- Combustion / gasification could be applied in limited cases for treatment of a solid waste where the moisture content was not too high. An example is treatment of dewatered and solar- dried (or previously stockpiled) sewage sludge.

- Fermentation for bioethanol has potential in the agricultural sector, but is currently limited to the availability of high carbohydrate-containing wastewaters such as those in the fruit processing and sugar-cane processing industries. Further separation of the fuel produced is energy intensive.

- Production of algal biomass for use in combustion, gasification, anaerobic digestion or for production of oils for biodiesel has attracted significant $R \& D$ interest. While many of these, especially biodiesel production is not yet feasible as a stand-alone technology, integrated technologies show potential.

Several risks, barriers and drivers to developing and implementing energy recovery from wastewater in South Africa were identified during this study. There is a general lack of research and implementation capacity and skills, and a greater need for research collaboration and information-sharing between research groups, government agencies and municipal practitioners. There is also no incentive for the generation of clean, renewable energy such as feed-in tariffs, green energy tariffs or peak tariffs. Benefits such as certified emission reductions and 
Table 3: Matching appropriate technologies to wastewaters

\begin{tabular}{|c|c|c|c|c|}
\hline \multicolumn{5}{|c|}{$\begin{array}{l}\text { Wastewater is characterised into those rich in organic dissolved solids, suspended solids and sludges } \\
\text { and the appropriate technologies with key operating parameters and energy efficiency are shown. }\end{array}$} \\
\hline Wastewater & Technology & Notes & $\begin{array}{l}\text { Key parameter } \\
\text { and range }\end{array}$ & $\begin{array}{c}\text { Efficiency } \\
\text { Energy/COD }\end{array}$ \\
\hline \multirow[t]{5}{*}{$\begin{array}{l}\text { Dissolved } \\
\text { solids }\end{array}$} & $\begin{array}{l}\text { Combustion and } \\
\text { gasification }\end{array}$ & Not applicable & - & - \\
\hline & Biogas & $\begin{array}{l}\text { Mature technology, applicable to majority of effluent } \\
\text { types. Optimum pH range of } 6.5-8.0 \text { and can be } \\
\text { inhibited by ammonia, sulphide and aromatic organics. } \\
\text { Incomplete COD reduction so polishing is normally } \\
\text { needed. Hydrogen production also possible, but } \\
\text { associated COD reduction minimal }(<15 \%)\end{array}$ & COD & $\begin{array}{l}0.2-0.45 \mathrm{~g} \mathrm{CH}_{4} \text { per g } \\
\mathrm{COD} \text { for } 10-23 \mathrm{MJ} / \mathrm{kg} \\
\text { COD or } 0.05-0.1 \mathrm{~g} \mathrm{H}_{2} \\
\text { per g COD for } 6-24 \\
\mathrm{MJ} / \mathrm{kg} \mathrm{COD}\end{array}$ \\
\hline & Bioethanol & $\begin{array}{l}\text { Current technology limited to fermentable sugar substrates. } \\
\text { Significant research into microbes that can ferment } \\
\text { cellulose is needed. Requires energy intensive distillation } \\
\text { to obtain pure product and generates high COD distillate } \\
\text { effluent, often containing recalcitrant organics. }\end{array}$ & $\begin{array}{l}\text { COD as fermentable } \\
\text { sugars }>25 \mathrm{~g} / \mathrm{L}^{\mathrm{a}} \\
\text { Total } \mathrm{COD}<250 \mathrm{~g} / \mathrm{L} \\
\text { to avoid osmotic } \\
\text { stress }\end{array}$ & $13 \mathrm{MJ} / \mathrm{kg}$ glucose \\
\hline & Algae for biodiesel & $\begin{array}{l}\text { Requires } \mathrm{N} \text { and } \mathrm{P} \text { as nutrients. Insignificant reduction in } \\
\mathrm{COD} \text {. Valuable filter cake as by-product. }\end{array}$ & $\begin{array}{l}\text { COD }<\text { discharge } \\
\text { specification }\end{array}$ & $\begin{array}{l}\text { Not applicable per } \\
\text { COD, but con- } \\
\text { servatively up to } 8 \\
\mathrm{~kJ} / \mathrm{m}^{3} / \text { day }^{\mathrm{b}}\end{array}$ \\
\hline & Microbial fuel cells & $\begin{array}{l}\text { Can reduce the COD from } 40-80 \% \text { of the input material } \\
\text { with conversion to electricity typically } 90 \% \text { efficient. }\end{array}$ & $\begin{array}{l}\text { COD from various } \\
\text { sources }\end{array}$ & $\begin{array}{l}200-300 \mathrm{~mW} / \mathrm{g} \text { COD } \\
\text { removed. Loading rate } \\
\text { of } 0.6 \mathrm{~kg} \mathrm{COD} / \mathrm{m}^{3} \text { per } \\
\text { day. }\end{array}$ \\
\hline \multirow[t]{5}{*}{$\begin{array}{l}\text { Suspended } \\
\text { solids }\end{array}$} & $\begin{array}{l}\text { Combustion and } \\
\text { gasification }\end{array}$ & Not applicable - must be dewatered first to give a sludge & - & - \\
\hline & Biogas & $\begin{array}{l}\text { Optimum pH range of } 6.5-8.0 \text { and can be inhibited by } \\
\text { ammonia, sulphide and aromatic organics. Incomplete } \\
\text { COD reduction so polishing is normally needed. Residence } \\
\text { time can be increased to facilitate acetogenesis. }\end{array}$ & TSS - wide range & $\begin{array}{l}0.2-0.45 \text { g CH} 4 \text { per g } \\
\text { COD } \\
10-23 \mathrm{MJ} / \mathrm{kg} \mathrm{COD}\end{array}$ \\
\hline & Bioethanol & $\begin{array}{l}\text { Current commercial technology not applicable unless prior } \\
\text { hydrolysis to fermentable sugars is performed. }\end{array}$ & - & - \\
\hline & Algae for biodiesel & Possible for algal cultivation, but no reduction in COD & - & - \\
\hline & Microbial fuel cells & Not applicable & - & - \\
\hline \multirow[t]{5}{*}{ Sludge } & $\begin{array}{l}\text { Combustion and } \\
\text { gasification }\end{array}$ & Depends on water content and the need for de-watering & \% water: $<75 \%$ & $15-20 \mathrm{MJ} / \mathrm{kg}$ dry \\
\hline & Biogas & $\begin{array}{l}\text { Optimum pH range of } 6.5-8.0 \text { and can be inhibited by } \\
\text { ammonia, sulphide and aromatic organics. Incomplete } \\
\text { COD reduction so polishing is normally needed. Increased } \\
\text { solids loading increases residence time. New pre-hydrolysis } \\
\text { processes can greatly improve yields. }\end{array}$ & $\%$ solids $3-10 \% c$ & $\begin{array}{l}2-0.45 \text { g } \mathrm{CH} 4 \text { per } \mathrm{g} \\
\mathrm{COD} \\
10-23 \mathrm{MJ} / \mathrm{kg} \mathrm{COD}\end{array}$ \\
\hline & Bioethanol & Not applicable & - & - \\
\hline & Algae for biodiesel & Not applicable & - & - \\
\hline & Microbial fuel cells & Not applicable & - & - \\
\hline
\end{tabular}

Notes:

a. Based on an energy efficiency value of 8 (Brazilian cane sugar) and relative to feed concentrations in SA molasses based plants. Assumes no energy input to pre-treat the effluent.

b. Based on algal productivity of $0.1 \mathrm{~g} / \mathrm{m} 2 /$ day, a pond depth of $15 \mathrm{~cm}$ and a lipid content of $30 \%$.

c. Typical value for sludge digestion, although "dry" anaerobic digestion technologies have been developed which can accommodate $25 \%$ solids

the production of other secondary products such as fertiliser could tip the balance of economic feasibility when implementing energy from a wastewater project.

Essentially, there is the need for the recognition of wastewater as a renewable energy resource that can further the aims of sustainable development by improving energy security while reducing the environmental footprints of activities. Additionally, the implementation of energy from wastewater projects could target essential services and the needs of communities currently not serviced by sewage and electrical infrastructure, with the aim of integrating the management of water, waste and energy. 


\section{Conclusion}

To enable the analysis of the potential for energy generation from wastewater, a rational technology choice model has been presented, matching wastewater characteristics quantitatively to the reviewed technologies. A review of potential wastewater streams available in South Africa for energy generation has been completed and their energy potential quantified. The formal and informal animal husbandry sector, fruit processing and beverage industries and domestic blackwater were identified as providing the highest potential. A survey of the energy recovery potential from all the wastewaters considered provides a first order estimate of approximately 3200 - $9000 \mathrm{MW}_{\text {th }}$ potential, which represents at best $7 \%$ of the current national power supply (approximately $140000 \mathrm{MW}_{\text {th }}$ or 42000 $\mathrm{MW}_{e}$ ).

\section{Acknowledgements}

The authors gratefully acknowledge support from the Water Research Commission of South Africa through funding of the WRC project K5/1732.

\section{References}

AGAMA Energy, 2007. Integrated biogas solutions. Available online: www.90x2030.org.za/oid\%5C downloads\%5CAgama\%20Biogas\%20technology\%20and\%20applications.pdf, accessed January 2012.

Alcock, N., 2009. Appropriate technology for reuse of sludge emanating from South African cities. M.Phil. Research Report, University of Cape Town, South Africa.

Bailey, J., \& Ollis, D., (1996). Biochemical Engineering Fundamentals, second ed. McGraw-Hill, New York.

Barsanti, L., \& Gualtieri, P., (2006). Algae: Anatomy, Biochemistry and Biotechnology. CRC Press, Boca Raton.

Chisti, Y., (2007). Biodiesel from microalgae. Biotechnol. Adv. 25, 294-306.

City of Vancouver, undated. Sewer heat recovery. Available online: http://vancouver.ca/commsvcs/ southeast/public/07mar13+15/sewerheatrecovery.pd f, accessed January 2012.

Department of Environmental Affairs and Tourism (DEAT), (2008). Long Term Mitigation Scenarios: Technical Report. Department of Environment Affairs and Tourism South Africa, Pretoria. October 2007.

Department of Minerals and Energy (DME), (2003). White Paper on Renewable Energy. Department of Minerals and Energy, Pretoria. November 2003.

Department of Water Affairs and Forestry (DWAF), 1998. DWAF Water Act of 1998. Available online: www.dwaf.gov.za/Documents/Legislature/nw_act/NW A.pdf, accessed January 2012.

ECOWORLD, (2006). Factory farmed biofuel. Available online: www.ecoworld.com/energy-fuels/factory- farmed-biofuel.html, accessed January 2012.

Emanti Water and Environmental Engineering Services, (2012). J. Environ. Manage. Available online: www.emanti.co.za/ewqms/env_info.htm, accessed January 2012.

IEA Bioenergy, (undated). Anaerobic digestion at Camphill Community Ballytobin, Ireland. Available online: www.aboutbioenergy.info/Camphill.html, accessed January 2012.

IEA Biogas, (undated). 100\% Biogas for urban transport in Linkoping, Sweden. Available online: www.ieabiogas.net/_download/linkoping_final.pdf, accessed January $20 \overline{12}$.

IGV GmbH, undated. Startseite. Available online: http://www.igv-gmbh.de, accessed January 2012.

ILEC (International Lake Environment Committee), (undated). Zeekoevlei. Available online: www.ilec. or.jp/database/afr/afr-17.html, accessed January 2012.

INNOVAS, DGE GmbH., undated. Industrial Biogas plant with wastewater treatment. Available online www.dge-wittenberg.de/english/produkte/alternativenergie/news11_eng.pdf, accessed January 2012.

Institute of Science in Society (ISIS), (undated). Biogas China. Available online: http://www.isis.org.uk/BiogasChina.php, accessed January 2012.

Ito, T., Nakashimada, Y., Senba, K., Matsui, T., \& Nishio, N., (2005). Hydrogen and ethanol production from glycerol-containing wastes discharged after biodiesel manufacturing process. J. Biosci. Bioeng. 100, 260265.

Jönsson, H., Stintzing, A.R., Vinnerås, B., \& Salomon, E., (2004). Guidelines on the use of urine and faeces in crop production. Stockholm Environment Institute. Available online: www.ecosanres.org./ pdf_files/ESR_Publications_2004/ESR2web.pdf, accessed January 2012.

Kiong, E., (2006). First biodiesel from sewage. Available online:

http://www.nzherald.co.nz/section/story.cfm?c id =1\& ObjectID $=10381404$, accessed January $201 \overline{2}$.

Leropoulos, I., Greenman, J., Melhuish, C., \& Hart, J., (2005). Energy accumulation and improved performance in microbial fuel cells. J. Power Sources. 145, 253-256.

Levin, D.B., Zhu, H., Beland, M., Cicek, N., \& Holbein, B.E., (2007). Potential for hydrogen and methane production from biomass residues in Canada. Bioresour. Technol. 98, 654-660.

Logan, B.E., Murano, C., Scott, K., Gray, N.D., \& Head, I.M., (2005). Electricity generation from cysteine in a microbial fuel cell. Water Res. 39, 942-952.

Logan, B.E., \& Regan, J.M., (2006). Electricity-producing bacterial communities in microbial fuel cells. Trends Microbiol. 14, 512-518.

Macleod, N., (2007). The state of the water and sanitation sector in South Africa. (2007). Available online: www.dwaf.gov.za/Masibambane/documents/structures/wsslg/jun07/WSSLG19Jun07WSState.pdf, accessed January 2012.

Min, B., Kim, J., Oh, S., Regan, J.M., \& Logan, B.E. (2005). Electricity generation from swine wastewater using microbial fuel cells. Water Res. 39, 4961-4968. 
Munoz, R., \& Guieysse, B., (2006). Algal-bacterial processes for the treatment of hazardous contaminants: A review. Water Res. 40, 2799-2815.

National Energy Regulator of South Africa (NERSA), (2009). South Africa Renewable Energy Feed-in Tariff (REFIT): Regulatory Guidelines.

Oswald, W.J., (1995). Ponds in the twenty-first century. Water Sci Technol. 31, 1-8.

Paustian, K., Cole, C.V., Sauerbeck, D., \& Sampson, N., (1998). $\mathrm{CO}_{2}$ mitigation by agriculture: an overview. Clim. Change. 40, 135-162.

Rabaey, K., Verstraete, W., (2005). Microbial fuel cells: novel biotechnology for energy generation. Trends Biotechnol. 23, 291-298.

Reith, J.H., van Doorn, J., Mur, L.R., Kalwij, R., Bakema, G., \& van der Lee, G., (2000). Sustainable co-production of natural fine chemicals and biofuels from microalgae. Proceedings of the Biomass for Energy and Industry Conference. 5-9 June 2000; Sevilla, Spain.

Rose, L.M., Dreyer, M.D., \& Fathi-Afshar S, (1981). The comparison of alternative technologies. Eng. Costs \& Prod. Econ. 5, 297-305.

Rose, P.D., Phillips, T.D., \& Sanderson, R., (1993). A process for the membrane-based extraction of $B$ carotene. RSA patent $94 / 0614$, USA patent 537,369; Australia patent 662,705.

Rossiter, A.P., (1995). Waste minimisation through process design. McGraw-Hill, New York.

Sazdanoff, N., (2006). Modelling and simulation of the algae to biodiesel fuel cycle. Columbus Ohio, Ohio State University, United States of America.

Shantaram, A.B., Veluchamy, H., \& Lewandowski, Z., (2005). Wireless sensors powered by microbial fuel cells. Environ. Sci. Technol. 39, 5037-5042.

Shipin, O.V., Meiring, P.G.J., \& Rose, P.D., (1998). Petro system: a low-technology approach to the removal of wastewater organics. Water SA. 24, 347-354.

Shuler, M.L., \& Kargi, F., (2002). Bioprocess Engineering. Prentice Hall, Upper Saddle River.

Singh, K.J., Sooch, S.S., (2004). Comparative study of economics of different models of family size biogas plants for state of Punjab, India. Energ. Convers. Manage. 45, 1329-1341.

Snyman, H., Water Research Commission, (2007). Personal communication.

South African Bureau of Standards (SABS), 1984. Act 30 of 1982. Government Gazette 18 May 1984 No. 9225. Available online: www.dwaf.gov.za/Dir_WQM/ docs/Leg_General\%20and\%20Special\%20Standards .doc, accessed January 2012.

Statistics South Africa, (2007). South African Community Survey. Available online: www.statssa. gov.za/community_new/content.asp, accessed January 2012.

Styrelsen för Internationellt Utvecklingssamarbete (SIDA), 2000. Water and Wastewater Management in Large to Medium-sized Urban Centers.

Techmonitor, (2005). Co-production of ethanol and energy. Available online: www.techmonitor.net/tm/ index.php?title=VATIS_Update_Non-conventional _Energy_.Jul-Aug_2005\#Co-production_of _ethanol_and_energy, accessed January 2012.
Tsukahara, K., \& Sawayama, S., (2005). Liquid fuel production using microalgae. J. Jpn. Pet. Inst. 48, 251-259.

van der Merwe, C., (2007). Cape Biogas-to-electricity project up and running. Available online: www.engineeringnews.co.za/article.php?a_id $=119702$, accessed January 2012.

VTT, (2006). St1 to launch production of ethanol using a technology developed by VTT Technical Research Centre of Finland. Available online: www.vtt.fi/uutta/ 2006/20060424.jsp?lang=en, accessed January 2012.

Wells, C.D., (2005). Tertiary treatment in integrated algal ponding systems. MSc thesis, Rhodes University, South Africa. Available online: http://eprints.ru.ac.za/206/, accessed January 2012.

World Energy Council, (2007). Survey of Energy Resources. Available online: www.worldenergy. org/publications/survey_of_energy_resources_2007/d efault.asp, accessed January 2012.

Received 1 February 2012; 5 December 2012 